\title{
Sectio caesarea criminalis
}

\author{
Szabó András dr.
}

Az emberiség történelme során a várandós anyákat időnként olyan atrocitások érték, amelyek leírásait olvasva elborzad a hétköznapi ember. Idetartoznak azok az esetek, amikor valamilyen hasi sérülés következtében jött világra a magzat. Ezeket gyakran megvadult ökrök, balesetek, de sokszor, sajnos, kegyetlen embertársaik okozták.

Mint sok minden másnak, ennek is megtalálható az előképe már a Bibliában is: „Hazáél megkérdezte: Miért sirsz, uram? Ö igy felelt: Mert megtudtam, hogy milyen veszedelmet hozol Izráel fiaira. Erödjeiket fölperzseled, ifjaikat fegyverrel ölöd meg, csecsemöiket szikláboz vágod, és terhes asszonyaikat felhasogatod." (Királyok könyve II. 8. 12.) „Meglakol Samaria, mert daczolt az ö Istenével. Fegyver által bullanak el; csecsemőik földhöz veretnek, és terhes asszonyaik ketté vágatnak." (Hóseás könyve 14. 1.)

Hérodotosz (Kr. e. 490-425) és Tacitus (55-116) arról tudósít, hogy a keleti népeknél háborúk idején szokás volt az előrehaladott terhesek hasát karddal felnyitni, és az így kimetszett gyermekekből azután engedelmes alattvalókat neveltek [1]. Így jártak el az ókori asszír hódítok is. A tatárok „A terhes asszonyokat éretlen magzatukkal együtt szétszaggatták, hogy megnézzék, bogyan fekszik a magzat az anyamébben, és gyönyörködve legeltették szemüket ez iszonyú anatómiai leckén" [2].

Gerhard Rohlfs (1831-1896) német Afrika-kutató írta le a következő borzalmas történetet "Quer durch Afrika” (1875) címú könyvében. A jelenleg Csád területén fekvő egykori Uadai (Wadai) szultánja, Mohammed és gyermekei, testvérei kegyetlenségükről voltak híresek. Egy alkalommal ketten közülük az utcán sétáltak, amikor szembe jött velük egy terhes asszony. Egyikük azt állította, hogy egy gyermeket hord a szíve alatt, a másik szerint ikreket. Megkérdezték az asszonyt, de ő nem tudott választ adni, ezért a vitát eldöntendő minden további nélkül felmetszették a hasát. Rohlfs szerint, aki 18651867-ben járt ott, az ilyen gyilkosságok és emberölések mindennaposak voltak [3].

Az örmény genocídium (1915-1917) idején a török katonák felvágták a várandós asszonyok hasát, előtte fogadtak, hogy fiú vagy lány a magzat. A helyzet azóta mit sem változott, mivel hasonló atrocitások a bosnyák holokauszt (1991-1995) és a ruandai etnikai harcok (1994) során gyakorta előfordultak. A bibliai idők borzalmai ismétlődnek napjainkban a Közel-Keleten is. Jászberényi Sándor 2014. augusztus 29-én kelt iraki krónikájában tudósít az iraki-kurdisztáni harcokról. Az úgynevezett Iszlám Állam (ISIS) szunnita harcosai mindenkit megöl- nek, aki nem szunnita. „Az idós és a terhes nöket késsel ölik meg, mert sajnálják rájuk pazarolni a töltényt. A terhes nóknek handzsárral felvágják a hasát és a szemük elött vágják félbe meg nem született magzatukat, csak utána vágják el a torkukat.”

Nem kevésbé hátborzongatóak a kisujjtalizmánnal kapcsolatos történetek. A bizarr talizmánokhoz terhes aszszonyokból kimetszett magzatok kisujjának levágása útján jutottak hozzá a bünözők.

Ludwig Strackerjan (1825-1881) német író és jogász 1867-ben megjelent munkájában olvasható, hogy Wardenburgban a rablók és gyilkosok felmetszették a terhes asszonyok hasát. Az ily módon kivett gyermekek ujjából gyertyákat csináltak. Ameddig ezek a gyertyák égtek, a ház lakói nem ébredtek fel. Annyi ujjnak kellett a rablónál lennie, ahányan a házban laktak [4].

Adolf Wuttke (1819-1870) német teológus 1869-ben a német babonákról írt könyvében említi, hogy a tolvajt megvédi az anyaméhből kivágott magzat kisujja [5].

Friedrich Kranss (1859-1938) horvát néprajzkutató 1890-ben megjelent, délszláv babonákkal foglalkozó munkájában írta, hogy Boszniában tolvajok és betörők megöltek egy hetedik hónapban lévő terhest, a gyermeket kimetszették az anyaméhből és vékony hosszú csíkokra vágták. Betöréskor a kiszárított csíkokat gyertyaként meggyújtották. Hitük szerint ettől a ház lakói úgy aludtak, mint a holtak, így nyugodtan rabolhattak [6].

A kisujjtalizmán a magyar irodalomban is feltűnik a XIX. századi betyárokkal kapcsolatban.

Krúdy Gyula (1878-1933) Rózsa Sándor életével foglalkozó, 1923-ban megjelent munkájának A postarablás címü fejezetében ezt írta: „-Te Imre, kinek van köztetek mébmagzatkisujja a ruhájába varrva? - kérdezte Rózsa Sándor. Egyik sem felelt a négy haramia közül. Tudták, hogy nem ok nélkül kérdezösködik Rózsa Sándor a babonás dolgaik után. Nagyot kell tennie annak, aki azt bevallja. - Tegnap még mindegyiknek volt a zsebében zártörö fü meg magzatujj” [7].

Móricz Zsigmond (1879-1942) „Rózsa Sándor a lovát ugratja" címú, 1941-ben megjelent regényében ez olvasható: „Halas városát villámgyorsan megjárta a bir. Hallotta-e már, komám, bogy Rozgonyi komámnak a tanyáját Rózsa Sándor felgyújtotta? - Hallottam, komám, de ha csak felgyújtotta vóna. Hanem vót neki egy nyomorult emberszógája, bizonyos Gárgyán Miska, egész családjával együtt lemészárolta. ... - De ha csak lemészárolta vóna, de a felesége éppen áldott állapotban vót, annak ha- 
sát kihasitotta, a csecsemónek a kisujját levágta, annak a világánál most már úgy lát, mintha mécsest hordana magánál. ...[Gárgyán Miskát] felakasztották, a feleségéből is kivágták a gyerököt. - A gyerököt? - Azt. Kell annak a kisujja a betyároknak” [8]. A szereplők neveiből arra lehet következtetni, hogy Rózsa Sándor 1836-ban történt Kiskunhalas környéki tehénlopásáról lehet szó. Az eset iratai fennmaradtak, de a Móricz által leírtakról nincs szó bennük [9].

Szenti Tibor hódmezővásárhelyi néprajzkutató „Betyártörténetek” című könyvéből tudhatjuk, hogy ez a kegyetlen rítus nem egyedi eset volt, és nemcsak Rózsa Sándor bandája gyakorolta (ha igaz), hanem az utolsó dél-alföldi betyár, Farkas Jancsi is a XIX. század utolsó harmadában. A Kérdő Szűcs Ernő nevű adatközlő a következőket mesélte: „Becseiné, Szatmáriék lánya emlitötte, hogy mönt kifelé a szögedi úton. Gyütt vele szömbe ëgy kocsi. Az asszony, Becseiné állapotos vót, ezért oszt fölvötte a kocsis, aki Farkas Jancsi vót maga. A beszélgetés során kiderült, hogy a komája lánya vót az utasa, Jancsi bácsi ezért nem vötte ki a hasábul a gyerököt, hogy lëvágja annak a sneveletlen ujját, vagyis a kisujját. Másként úgy elvitte vóna az asszonyt, hogy nem látta vóna többet a napot! Ögyébként, Farkas Jancsi mondta a nagyapámnak, hogy a kivágott gyerökujj éccaka világit... Szóval, varázsereje van neki” [10].

A kisujjtalizmán megszerzéséről Móra Ferenc (18791934) 1927-ben a Délmagyarország címú szegedi napilapban megjelent, Rózsa Sándorról írott cikkében mint valós eseményról szólt: „... a haramia urak Péterin egy áldott állapotos asszonyt azért öltek meg, hogy hozzá juthassanak a még meg nem született magzat kis ujjához. Úgy tartották, hogy az a leghathatósabb talizmán s akinek olyan van a szürujjába kötve, azt nem fogja a zsarók golyója”[11]. Nem tudjuk, hogy Móra Ferenc értesülése honnan származott. A megállapítás, sajnos, csak a helyszínt említi mint Péteri, valószínúleg Péteri-puszta (ma Pálmonostora, Bács-Kiskun megye), ahol Rózsa Sándor sikertelen vonatrablása történt 1868-ban.
Figyelemre méltó, hogy Krúdy is, Móricz is milyen szenvtelenül írta le a borzalmas rituálét. Vajon olvasták-e Móra Ferenc fent említett cikkét, amelyben élesen kikelt a romantikus betyárkultusz ellen: „... magam nem vagyok bajlandó nagy hazámfiának vállalni Sándort”. Majd ezt írta: „Sighele olasz kriminológusnak van egy érdekes könyve a bün presztizsérôl, ami öszerinte tagadhatatlanul nagyobb, mint a szegény erénynek a presztizse. Biz' ez nem válik valami nagy becsületére az emberi fajzatnak, de be kell ismerni, igen csak igy szokott lenni falunvároson.”

\section{Irodalom}

[1] Weiss, P. A.: Sectio Caesarea und assoziirte Fragen. Springer Verlag, Wien, 1994. [German]

[2] Tóth, G. P.: Body. [Corpus.] Korunk, 2003, 14(3), 46-57. [Hungarian]

[3] Rohlfs, G.: Quer durch Afrika. Europäischer Hochschulverlag, Bremen, 2010. [German]

[4] Strackerjan, L.: Aberglaube und Sagen aus dem Herzogthum Oldenburg. I. G. Stalling, Oldenburg, 1867. [German]

[5] Wuttke, A.: Der deutsche Volksaberglaube der Gegenwart. Wiegand und Grieben, Berlin, 1869. [German]

[6] Kranss, F.: Volksglaube und religiöser Brauch der Südslaven. Aschendorff, Münster, 1890. [German]

[7] Kruidy, Gy.: Rózsa Sándor. The star of the scamps in the Hungarian history. [Rózsa Sándor. A betyárok csillaga Magyarország történetében.] Móra-Kárpáti-Madách, Budapest-UzsgorodBratislava, 1989. [Hungarian]

[8] Móricz, Zs.: Rózsa Sándor is getting his horse to jump. I. [Rózsa Sándor a lovát ugratja. I.] Szépirodalmi Kiadó, Budapest, 1959. [Hungarian]

[9] Szentesi Zöldi, L.: First case of Rózsa Sándor. [Rózsa Sándor első búnügye.] Halasi Múzeum, 2009, 3, 123-128. [Hungarian]

[10] Szenti, T.: Scamp-stories. [Betyártörténetek.] Mayer Nyomda és Könyvkiadó, Budapest, 1999. [Hungarian]

[11] Móra, F.: About the Sándor's memory. [A „Sándor” emléke körül.] Délmagyarország, 1927. February 6. [Hungarian]

(Szabó András dr., Szentes, Csongrádi út 18., 6600 e-mail: szabodoktor@gmail.com) 